\title{
Internships in kindergartens as a resource for development of practices with different quality levels
}

\author{
Tatiana Le-van ${ }^{1 *}$, Larisa Loginova ${ }^{1}$, Olga Shiyan ${ }^{1}$, Anna Iakshina $^{1}$, and Igor Shiyan ${ }^{1}$ \\ ${ }^{1}$ Moscow City University, Institute of System Projects, Laboratory of Child Development, Moscow, \\ Russia
}

\begin{abstract}
Professional development of teachers is recognized worldwide as an important condition for high quality education. According to experimental data, pre-service and in-service training programs of preschool teachers are not always efficient, their interrelation with provisions for quality development in kindergartens is inconsistent. Developing potential of internship as a form of professional growth reduces deficiencies of programs focused on achievements of the kindergarten, on teaching technics without discussion of their worthiness and preschool values, perfunctory discussion, rigidity, organizational disadvantage. The authors discuss the criteria of effective internship. Programs work both to give specific knowledge and master pedagogical techniques, and, at the same time, to develop reflection. Programs support participants to adopt the cycle of pedagogical action. This research is aimed at selection of best practices of preschool education and analysis of their potential in internship. The research participants are Moscow teachers of 50 preschool groups. The groups, ready for internships, demonstrate significantly higher quality of education than the joint sample; however, they experience the lack of competences in work with adults and in development of their reflection. The internship programs elaborated by teachers from high quality groups show some deficiencies, namely, different topics interfere in one short-term program, the main focus is on object-spatial environment but not on interaction, participants' outcomes are not embodied in any product. Best practices are interested in their own development as well as new sources of motivation. The authors have proposed internship to become a resource of development both for organizers and participants. Each position solves its own problems.
\end{abstract}

Keywords: preschool education quality, internship, good practice, professional development.

\footnotetext{
*Corresponding author: levantn@mgpu.ru
} 


\section{Introduction}

Efficiency of investments into improvement of education quality and importance of professional development of teachers are recognized worldwide [1-2]. However, relationship between qualification improvement and development of quality provisions in kindergartens is sometimes inefficient and inconsistent: in some works, it is traced [3-4], in other works, it is not [5-7]. In inefficient learning programs, the work with teachers' concepts of good quality is too short and far from analysis of their own practice. The acquired knowledge and declared values are in contradiction with their implementation [6-7]. This is due to incomprehension of the way to create required provisions in class. Such in-service training programs are often not focused on development of teacher's key competence: ability to keep balance between solution of educational tasks and interests of a child. The challenge faced by a teacher in everyday work is the need to be sensitive to children while expanding their capabilities, not only to follow them but also to propose cultural facilities [8-9]. Reflective pedagogical action and its embodiment into pedagogical cycle (observation-planning-action-observation) allow solving this problem [10]. (Figures 1,2).

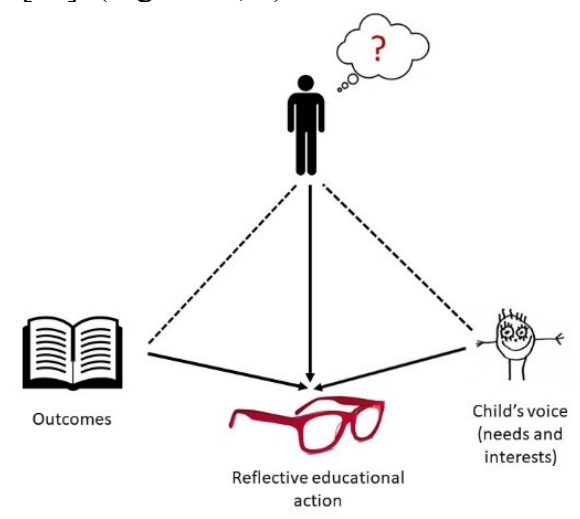

Fig. 1. Model of reflective action.

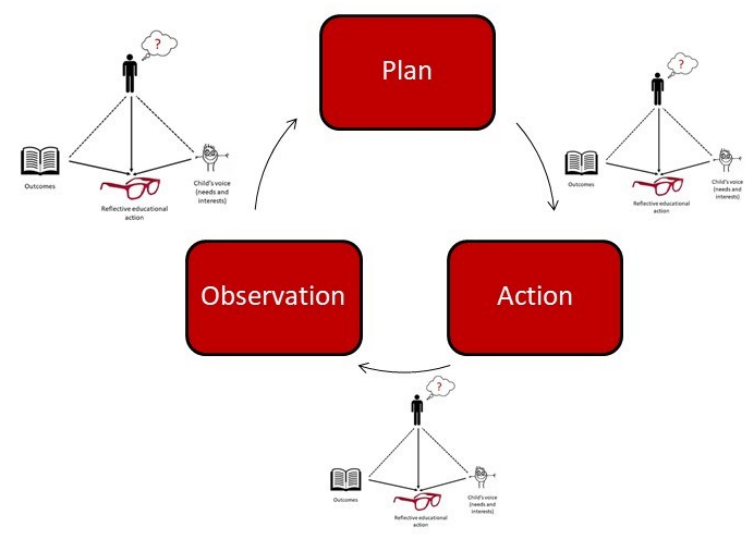

Fig. 2. Cycle of pedagogical action.

If training program doesn't include practice, in this case potential of teachers' community, peer teaching and team work is not used [11-12]. Herewith, researchers mention that the 
competences of organization team work, mentor's reflective position do not emerge by themselves and require some training [13].

Efficient program of professional development should be focused not only on obtaining specific knowledge and mastering teaching technics but also on development of professional reflection, further mentoring, and supervision [14-16]. The main methods of teachers' reflection development are group discussion, feedback, reflective diaries, comparison of own practice with theoretical approaches, mentoring (moreover, both trainee and mentor positions can support reflection development), self-assessment, analysis of video [13, 17-19].

Analysis of Russian practice of preschool teachers' in-service training (peer teaching, guesthood, internships) allows to detect some deficiencies:

- Program is oriented not on exploring the teacher's everyday work but rather on demonstration of ECEC service success in general: tours around building, presentations of achievements, public classes with children.

- Internship is often focused on technical aspects of the practice and do not suggest discussion of its worthiness and values.

- The discussions are perfunctory and do not distinguish different points of view.

- The individual request of interns is not considered, there is no support of their zone of proximal development, flexibility in content and forms of work is not allowed.

Even the programs free from these deficiencies contain gaps in the cycle of pedagogical action: interns' practical attempts sometimes are not based on preliminary observation of children, or, on the contrary, the observation is not transformed into own practical steps, reflection does not accompany all learning stages. This is accompanied with organizational inconvenience: high number of interns in a class interrupt usual daily routine, teachers switch from their direct responsibilities to the trainees, short-term internship doesn't allow to get acquainted with the environment and the children before try actions, it creates discomfort both for children and adults.

Reliable procedures to select best practices which can disseminate of their experience are not available. Therefore, internships are performed not by the best practices. Internship organizers often do not consider implementation of the program as a useful resource for their own professional development.

\section{Problem statement}

Reproducing of efficient practice as a method of in-service training doesn't make sense, because it is impossible to copy another's actions: in each service, a unique situation is established each program has its own specificity, characteristics of children and teaching staff differ. Internship is aimed not at collecting pedagogical portfolio of certain methods and technics (the often result is uncritical and eclectic borrowing) but at mastering the methods of solving professional problems: managerial, methodical, etc., that is, at mastering methods of reflective action construction.

Herewith, kindergartens, ready to act as internship sites, though demonstrating sufficiently high quality of education, often experience the lack of competences to work with adults. This becomes their new source of motivation.

The way out of this situation can be that internship becomes the resource orf development of all participants solving different problems. It will happen if the teams of preschool groups with good quality use the situation of training for development of their own practice while preparing video and photo cases for discussion, conduct debates and workshops about these cases. 


\section{Methods}

The Laboratory of Child Development (Moscow City University) conducted the project Internship: the best practices, revealed best practices of preschool education, and performed analysis of their potential as internship sites.

The method of nonparticipant expert observation was applied using ECERS-3 [20]. Fifty preschool groups participated in the research, sampling was declaratory: all schools with preschool groups and kindergartens in Moscow were informed $(n=587)$, the directors filed applications that they had a practice of good quality and were interested in involving it as internship program provider. The assessment instrument and criteria were discussed with participants before the research. Confidentiality of results was guaranteed.

The data were processed by descriptive statistics, cluster analysis, followed by verification of significant difference (Welch's t-test without assumption of dispersity equality, though with assumption of distribution normality; existence of differences was verified using Wilcoxon rank sum test).

For teachers of the selected practices the program was developed to train internships methodology. The program was tasted in a group of 33 teachers from 11 services, and included mastering the professional action cycle and training technics for adults (three faceto-face reflective seminars and homework). Then, two meetings were organized for presentation of internship programs developed by the participants (11 projects). Qualitative analysis of the projects was performed by independent experts in terms of the following criteria: relevance and concentration of topic, content flexibility, organizational balance (mode and forms of work; ratio of participants' categories), consideration for cycle of pedagogical action, relevance of final product.

\section{Results}

Analysis of observation data demonstrates that mean score in joint sample equals 3.04 $(\mathrm{sd}=0.72$; med=3.06; score: $\mathrm{Min}=1.76, \mathrm{Max}=4.56)$. In the "Interaction" and "Program Structure" subscales, the score was maximum (reached 4.00), and for "Lanquage and Literacy" and "Learning Activities", it was minimum (below 3.00). On this background, the cluster of contrast groups was selected, which passed psychological mark of 3.50 in terms of total mean score and 4.00 in terms of interaction $(n=12)$ : mean $=3.99(\mathrm{sd}=0.34$, med $=3.88$; $\operatorname{Min}=3.53$, Max=4.56).

Verification of the hypothesis about significant differences between total sampling and selected cluster demonstrates that in terms of total score and for all subscales, except for one, the differences were significant at $\alpha=0.01$ (for total mean score: $p$-value $=5.47 \mathrm{e}-08$ according to Welch's t-test and $5.02 \mathrm{e}-05$ according to Wilcoxon test; by subscales: according to Welch's t-test, p-value $\min =8.57 \mathrm{e}-07$ for "Interaction", $\max =0.0063$ for "Language and Literacy"; according to Wilcoxon test: in the mentioned ranges). For the "Personal Care Routines" subscale, the differences of mean scores were insignificant.

Kindergartens of the selected cluster were stated as best practices. They proposed to be internship sites and get enrolled into preliminary training program which includs development of their own internship program and its discussion with experts of Laboratory of Child Development (MCU).

Qualitative analysis of elaborated programs revealed the following deficiencies of participants:

- Mix of various topics in one short-term program.

- Focus on spatial environment and not on interaction.

- Gap in cycle of pedagogical action (despite highlighted key stages, no link between them).

- No introduction stage (acquaintances, collecting requests, discussion of values, etc.). 
- No final product.

This identifies growth points for internship sites development.

\section{Discussion}

The results of observation revealed both old and new norms in understanding quality of preschool education by participants. The new norm is oriented towards provisions of national standard: support of children's development, choice, autonomy, balance between teacherinitiated and child-initiated activities [21]; and the old one copies outdated model of school frontal classes based on subject knowledge and skills. Selection of best practices showed that they are not ideal, had deficiencies in certain aspects of quality; however, they are in search and have already objectively strong solutions in the frames of transition into new norm.

Analysis of the elaborated programs has demonstrated that an internship site should be best practice not only in terms of working with children; the skills in training adults are required in regard to their zone of proximal development. Intuitive understanding of the cycle of pedagogical action is maintained only in work with children, and it is not implemented with adults.

The training activity discovered that providing internship program can be a powerful resource for development of practice itself. Due to interaction with colleagues sharing different opinions, best practices can detect own deficiencies.

The internship format with expert supervision combines several meaningful aspects: development of reflection, working with community, immersion in practice and analysis of its efficient methods and technics from inside position; combination of theoretical notions with their implementation, verification of their work in field conditions. This is supplemented by the fact that interns have their own professional experience and opinions, and, using these habits, are engaged during training into dialogue with the observed practice; hence, their professional orientations are strengthened or transformed. Additional important effect of internships is mastering methods to work with teachers.

\section{Conclusion}

A reliable method to select best practices is quality assessment of learning process by external experts using verified tools.

Internship can become a point of growth for practices with various quality levels:

- $\quad$ Kindergartens with low quality level: opportunity to meet not only another way of work but also reflection of their own values due to such meeting and developing seminars.

- $\quad$ Kindergartens, where modifications have already been initiated, can master efficient methods of working with children and reflect on their differences from the regular ones.

- Kindergartens with high quality level: the necessity to address colleagues creates the situation of dialogue, important for reflection of their own framework and development of practice.

The research restrictions include declaratory principle of sampling: some practices could not be declared due to ideas of their heads about old norms. In the future, it is important to provide expert support and supervision of internship sites, which would provide improvement of teachers' experience more efficiently.

\section{References}

1. E. Melhuish, Provision of quality early childcare services. Synthesis Report (Publications Office of the European Union, Luxembourg, 2016) 
2. I. Siraj, S.J. Howard, D. Kingston, C. Neilsen-Hewett, E.C. Melhuish, M. de Rosnay, The Australian Educational Researcher, 46, 365-383 (2019). https://doi.org/10.1007/s13384-019-00325-3

3. S.C. Hartman, B. G. Warash, R. Curtis, J. D. Hirst, Early child development and care, 186(12), 1952-1960 (2016)

4. P.L. Slot, Structural characteristics and process quality in early childhood education and care: A literature review. OECD Education Working Paper No. 176 (OECD, Paris, 2018)

5. I. Shiyan, S. Zadadaev, T. Le-van, O. Shiyan, EpSBS, 43, 602-610 (2018). https://dx.doi.org/10.15405/epsbs.2018.07.80

6. J.A. Vu, M. Han, M.J. Buel, European Early Childhood Education Research Journal, 23(4), 444-460 (2015). https://doi.org/10.1080/1350293X.2015.1087144

7. A. Devi, M. Fleer, L. Li, International Journal of Early Years Education, 26(3), 295311 (2018). https://doi.org/10.1080/09669760.2018.1452720

8. N.E. Veraksa, Cultural-Historical Psychology, 14(2), 102-108 (2018). https://doi.org/10.17759/chp.2018140211

9. N. Pramling, C. Wallerstedt, P. Lagerlöf, C. Björklund, A. Kultti, H. Palmér, M. Magnusson, S. Thulin, A. Jonsson, I. Pramling Samuelsson, Play-responsive teaching in early childhood education (Springer, Cham, 2019). https://doi.org/10.1007/978-3030-15958-0

10. O.A. Shiyan, A.N. Yakshina, S.A. Zadadayev, T.N. Le-van, Modern preschool education. Theory and Practice, 4(94), 14-35 (2019). https://doi.org/10.24411/19979657-2018-10049

11. E. Wenger, Communities of practice: Learning, meaning and identity (Cambridge University, Cambridge, 1998)

12. V. Tietze, S. Fiernickel, I. Dittrich, K. Grenner, A. Hanisch, J. Marx, Assessment and development of the quality of preschool education (Mozaika-Sintez, Moscow, 2018)

13. K. Thornton, The impact of mentoring on leadership capacity and professional learning, in Mentoring in early childhood education: a compilation of thinking, pedagogy and practice (NZCER, Wellington, 2015)

14. A.M. Coffey, Australian Journal of Teacher Education, 39(9) (2014). http://dx.doi.org/10.14221/ajte.2014v39n9.7

15. J. Peeters, C. Cameron, A. Lazzari, B. Peleman, I. Budginaite, H. Hauari, H. Siarova, Working conditions, training of early childhood care workers and quality of services A systematic review (Publications Office of the European Union, Eurofound, Luxembourg, 2015)

16. E. Lampert-Shepel, C. Murphy, Journal of Cognitive Education and Psychology, 17, 278-300 (2018). https://doi.org/10.1891/1945-8959.17.3.278

17. S. Sheridan, Early Child Development and Care, 164, 63-78 (2000). https://doi.org/10.1080/0300443001640106

18. B. Raban, A. Nolan, M. Waniganayake, C. Ure, J. Deans, R. Brown, Journal of Australian Research in Early Childhood Education, 12(2), 1-16 (2005)

19. L.K. Doan, Canadian Children, 38(2), 21-24 (2013). https://doi.org/10.18357/jcs.v38i2.15447

20. T. Harms, D. Cryer, R.M. Clifford, ECERS-3. Shkaly dlya kompleksnoy otsenki kachestva obrazovaniya $v$ doshkol'nykh obrazovatel'nykh organizatsiyakh [ECERS-3. 
Early Childhood Environment Rating Scale] (Natsionalnoye obrazovaniye, Moscow, 2019)

21. Federal State Educational Standard of Preschool Education. Site of the Ministry of Education of the Russian Federation (2013). http://минобрнауки.рф 